\title{
Soil acid phosphomonoesterase activity and phosphorus forms in ancient and post-agricultural black alder [Alnus glutinosa (L.) Gaertn.] woodlands
}

\author{
Anna Orczewska ${ }^{1 *}$, Anna Piotrowska ${ }^{2}$, Joanna Lemanowicz ${ }^{2}$ \\ ${ }^{1}$ Department of Ecology, University of Silesia, Bankowa 9, 40-007 Katowice, Poland \\ 2 Department of Biochemistry, University of Technology and Life Sciences, Bernardyńska 6, 85-029 Bydgoszcz, Poland
}

\section{Abstract}

Black alder, an $\mathrm{N}$-fixing tree is considered to accelerate the availability of phosphorus in soils due to the increased production of phosphatase enzymes, which are responsible for the P release from the litter. Acid phosphatase activity plays a pivotal role in organic P mineralization in forest soils and in making P available to plants. In order to check whether Alnus glutinosa stimulates acid phosphomonoesterase $\left(\mathrm{PH}_{\text {ACII }}\right)$ activity, we compared enzyme activities, total $\mathrm{P}$ concentration $\left(\mathrm{P}_{\text {TOT }}\right)$, plant-available $\mathrm{P}\left(\mathrm{P}_{\text {AVAI }}\right)$, organic $\mathrm{P}\left(\mathrm{P}_{\mathrm{ORG}}\right)$ and inorganic $\mathrm{P}\left(\mathrm{P}_{\text {INORG }}\right)$, and organic matter content in 27 ancient and 27 post-agricultural alder woods (the latter ones representing different age classes: 11-20, 21-40 and 41-60 years) of soil samples taken from the litter and the mineral layers. Phosphomonoesterase activity, organic matter, $\mathrm{P}_{\mathrm{TOT}}, \mathrm{P}_{\mathrm{INORG}}$ and $\mathrm{P}_{\mathrm{ORG}}$ concentrations were significantly higher in ancient alder woods than in the soils of post-agricultural forests. Significant differences in the acid phosphatase activity, organic matter and $\mathrm{P}_{\text {AVAIL }}$ concentration were noted between the litter and mineral layers within the same forest type. In recent stands the amount of organic matter and phosphatase activity increased significantly with the age of alder stands, although only in the mineral layer of their soils. Phosphomonoesterase activity, organic matter and $\mathrm{P}_{\text {AVAIL }}$ content were higher in a litter layer and decreased significantly at a mineral depth of the soil. The acid phosphatase activity was significantly correlated with organic matter content in both ancient and recent stands. There was no significant relationship between $\mathrm{PH}_{\mathrm{ACID}}$ activity and any $\mathrm{P}$ forms.

Keywords: acid phosphatase activity, soil P forms, Alnus glutinosa-dominated woodlands, south-western Poland

\section{Introduction}

Several phosphatases are involved in the hydrolysis of organic $\mathrm{P}$ compounds but the major role in the organic phosphorus mineralization process is attributed to the phosphomonoesterases. Acid phosphomonoesterase enzymes are the dominant group of enzymes involved in organic P mineralization in acidic soils [1]. These enzymes are produced mainly by plants and fungi and to a lesser degree by bacteria. The level of acid phosphomonoesterase secreted by plant roots has been shown to differ significantly between species, with $\mathrm{N}$-fixing plants (legumes) secreting more phosphomonoesterase enzymes than cereals [2]. Plant available $\mathrm{P}\left(\mathrm{P}_{\text {AVAII }}\right)$ concentration also increases in soils underlying plantations of $\mathrm{N}$-fixing trees [1], probably due to a higher $\mathrm{P}$ requirement by $\mathrm{N}$-fixing plants [3]. The relationship between the available $\mathrm{P}$ concentration and phosphatase activity is usually very complex, since a positive, a negative or no relationship

*Corresponding author. Email: anna.orczewska@us.edu.pl

This is an Open Access digital version of the article distributed under the terms of the Creative Commons Attribution 3.0 License (creativecommons.org/licenses/by/3.0/), which permits redistribution, commercial and non-commercial, provided that the article is properly cited. between these two parameters is possible [1,4]. There are studies which show that phosphatase activity is inversely proportional to the $\mathrm{P}_{\text {AVAIL }}$ concentration [5], which confirms the thesis that the production and activity of soil phosphatases, especially the acid form, is connected with the demand of microorganisms and plants for P. Phosphatases are typical adaptive enzymes and their activity increases when plant available $\mathrm{P}$ concentration decreases. Kinetics studies indicate that orthophosphate ions, which are the product of the reaction conducted by the phosphatases, are competitive inhibitors of their activity in soil [6]. Other studies have found a significant positive correlation between phosphatase activity and available $\mathrm{P}$ concentration. Generally, a significant and positive relationship between phosphatase activity and P availability [7] is obtained in unfertilized soils or/ and those with a low content of nutrients, where $P$ deficiency occurs. On the contrary, in soil where P fertilizers are applied and/ or in naturally fertile soil a significant but negative relationship between both of these parameters can be observed [4].

It is a well known fact that trees can alter soil conditions, thus influencing ecological processes such as secondary succession and plant migration. Black alder [Alnus glutinosa (L.) Gaertn.] can have a great impact on its habitats and can form a symbiosis with Frankia and with ectomycorrhizal fungi. The actinobacteria provide the tree with $\mathrm{N}$ fixed from the atmosphere, whereas mycorrhizal fungi provide $\mathrm{P}$ and other nutrients [8], and on the other hand alders provide energy to microsymbionts [9]. Therefore, they play an important role 
in cycling of $\mathrm{N}$ and other nutrients $[9,10]$ even in poor soils, and they contribute to an increase in concentrations of $\mathrm{N}, \mathrm{P}$, $\mathrm{C}$ and other nutrients [11]. However, in the case of available $\mathrm{P}$ contradicting results have been reported since Compton and Cole [10] found a decrease whereas Bormann et al. [12] and Giardina et al. [13] observed an opposite trend. Although the influence of Alnus glutinosa on P transformation processes have been often investigated [10-13], acid phosphomonoesterase activity $\left(\mathrm{PH}_{\mathrm{ACID}}\right)$, the main enzyme responsible for organic $\mathrm{P}$ mineralization in forest soils, has been poorly studied [14]. Soils under post-agricultural woods contain larger P amounts than soils under ancient woodlands (the latter ones are understood sensu de Keersmaeker et al. [15], Koerner et al. [16], and Peterken [17]). Therefore, the increased P level in soils covered by recent woods is taken as an indicator of their former agricultural use $[15,16]$. However, recent comparative studies between ancient and post-agricultural forests with stands dominated by black alder exhibited a reverse behaviour with continuously forested soils richer in available $\mathrm{P}$ than soils of former meadows currently occupied by black alder stands. Furthermore, the available $\mathrm{P}$ concentration in soils under recent, post-agricultural alder woodlands gradually increased with stand age [18]. The presence of black alder could be the reason for this increase in available $\mathrm{P}$, since $\mathrm{N}$-fixing trees influence $\mathrm{P}$ cycling as mentioned above, also through the increased production of phosphomonoesterase [14]. Thus the above mentioned results may confirm indirectly the hypothesis by Binkley [14] on the influence of black alder on phosphomonoesterase enzymes. To have more direct evidence about this hypothesis we have conducted a research whose objective was to determine whether Alnus glutinosa stimulates acid phosphomonoesterase activity and influences $\mathrm{P}$ transformation processes, by comparing $\mathrm{PH}_{\mathrm{ACID}}$ activity and some $\mathrm{P}$ forms concentration [total $\mathrm{P}\left(\mathrm{P}_{\mathrm{TOT}}\right)$, organic $\mathrm{P}\left(\mathrm{P}_{\mathrm{ORG}}\right)$, inorganic $\mathrm{P}$ $\left.\left(\mathrm{P}_{\text {INORG }}\right), \mathrm{P}_{\text {AVAIL }}\right]$ in soils covered by black alder stands with different site histories (ancient versus post-agricultural) and with different ages of recent stands established after agricultural use.

\section{Material and methods}

\section{Study area description and soil sampling}

The studies were undertaken in south-western Poland in two geographic regions: the Oleśnica Plain $\left(51^{\circ} 04^{\prime} \mathrm{N} ; 17^{\circ} 43^{\prime} \mathrm{E}\right)$ belonging to Opole Silesia and the Żmigród Valley $\left(51^{\circ} 28^{\prime} \mathrm{N}\right.$; $16^{\circ} 54^{\prime} \mathrm{E}$ ), which is located in Lower Silesia. Both regions have a high proportion of forests in their landscape (33.7\% and $41.2 \%$, respectively) and also a high proportion of ancient woodlands (77\% and $70 \%$ of the overall forest cover, respectively) [19]. Annual average temperature reaches $8.1-8.5^{\circ} \mathrm{C}$, with a minimum in January $\left(-1.9^{\circ} \mathrm{C}\right)$ and the maximum in July $\left(18.5^{\circ} \mathrm{C}\right)$. Annual average rainfall reaches $580-650 \mathrm{~mm}$ and the vegetation season lasts 215-225 days (compared with the 200 days being the average for Poland).

The ancient woodland sites varied in size from 0.73 ha to $15.5 \mathrm{ha}$, whereas the area of the recent woods ranged from 0.72 ha to 8.6 ha. The stand in ancient woods is dominated by black alder and they represent the following forest communities: wet types of oak-hornbeam forests, alder-ash carrs and typical wet alder woods. Recent black alder woods, adjacent to ancient woods, were planted on former meadows. The stands of recent woods were grouped in the following age classes: 11-20 years
(10 sites), $21-40$ years (11 sites) and 41-60 years (6 sites). The alder forests investigated grow on meso- and eutrophic soils, and on moist, wet or periodically waterlogged sites. Humic Gleysols, with moist and wet mull and moist moder-mull humus were the predominant soils [18].

Soil samples from the litter (humus) layer and the mineral soil were taken in late September, 2009, before leaf fall. Samples were taken from adjacent 27 ancient forests and 27 postagricultural stands by Edelman-corer $(\varnothing=7.5 \mathrm{~cm})$. In each forest area 10 samples from randomly scattered locations were collected and then a bulk sample was prepared. In total 108 bulk soil samples were collected ( 27 ancient woods $\times 2$ layers, 27 recent woods $\times 2$ layers). Upon arriving at the laboratory, field-moist samples were sieved $(<2 \mathrm{~mm})$, stored at $4^{\circ} \mathrm{C}$ in a plastic box and then moistened to $50 \%$ WHC and preincubated at $25^{\circ} \mathrm{C}$ for 7 days prior to phosphatase activity determination. Soil samples were analyzed for $\mathrm{P}$ forms, $\mathrm{pH}$ and organic matter content after air-drying at room temperature.

Data on soil type and humus type under alder woods investigated were from [18]. Nomenclature of soil types was given after World Reference Base [20], and the classification of humus forms was after Prusinkiewicz [21].

\section{Chemical and biochemical analyses}

Soil $\mathrm{PH}_{\mathrm{ACID}}$ activity was determined as described by Tabatabai and Bremner [22]. Soil $(1 \mathrm{~g})$ was incubated at $37^{\circ} \mathrm{C}$ with $4 \mathrm{ml}$ of Modified Universal Buffer (MUB) at pH 6.5 and $1 \mathrm{ml}$ of 0.05 $\mathrm{M}$ sodium $p$-nitrophenolphosphate. After $1 \mathrm{~h}$ of incubation the reaction was stopped by adding $1 \mathrm{ml} 0.5 \mathrm{M} \mathrm{CaCl}_{2}$ and $4 \mathrm{ml} 0.5$ $\mathrm{M} \mathrm{NaOH}$. After mixing, the soil suspension was filtrated by a two folded filter paper (Whatman No. 42) and the optical density of the reaction product ( $p$-nitrophenol) was measured spectrophotometrically at $400 \mathrm{~nm}$. One control used autoclaved soils to evaluate the spontaneous or the abiotic transformation of the substrate, whereas in the other control the substrate was added to soil after incubation and immediately prior stopping the reaction. The enzyme activity was done on fresh, moist, sieved $(<2 \mathrm{~mm})$ soil samples. One unit of acid phosphatase activity was defined as the number of mmoles of $p$-nitrophenol released by $1 \mathrm{~kg}$ of an dried soil at $37^{\circ} \mathrm{C}$ per $1 \mathrm{~h}\left(\mathrm{mM} \mathrm{pNP} \times \mathrm{kg}^{-1} \times \mathrm{h}^{-1}\right)$.

The $\mathrm{P}_{\text {AvaIL }}$ was determined by the method involving the use of acetate-lactate ammonium solution at $3.7 \mathrm{pH}$. The $\mathrm{P}_{\text {тот }}$ was determined as described by Mehta et al. [23], by treating soil with concentrated $\mathrm{HCl}$ and then with $0.5 \mathrm{M} \mathrm{NaOH}$ at room temperature and at $90^{\circ} \mathrm{C}$. After mixing the extracts were mineralized with a respective mixture of concentrated acids: nitric acid (V), perchloric acid (VII) and sulfuric acid (VI) at a ratio of 10:1:4. After mineralization, the optical density was assayed at $660 \mathrm{~nm}$. The $\mathrm{P}_{\text {ORG }}$ concentration was calculated as the difference between the total and inorganic $\mathrm{P}$ concentration.

All spectrophotometric measurements were done with a UVVIS spectrophotometer Lambda 11 (Perkin Elmer).

Soil organic matter content (\% of dry matter) was measured as a weight-loss at $550^{\circ} \mathrm{C}$ for $5 \mathrm{~h}$ in a muffle furnace. The $\mathrm{pH}$ was measured with 1:2.5 soil: $1 \mathrm{M} \mathrm{KCl}$ solution suspensions using a glass electrode.

Each sample was analyzed in triplicate for all properties studied.

\section{Statistical analyses}

Significant differences in phosphomonoesterase activity and in the concentration of the measured soil chemical parameters between the litter layer in ancient vs. recent woods and for the 
mineral layers in ancient vs. recent forests, were assessed applying the Mann-Whitney U-test. The same procedure was used to check whether differences in $\mathrm{PH}_{\mathrm{ACID}}$ and $\mathrm{P}$ forms concentration exist between the litter vs. mineral layers of soils in ancient and in recent woods. In order to understand the stability of each soil properties studied their variability between woodland types and soil depths was compared using coefficient of variation $[C V(\%)]$, which values of $0-15 \%, 16-35 \%$, and $>36 \%$ indicate low, moderate and high variability, respectively [24]. To check whether significant differences exist in the chemical and biochemical soil parameters among post-agricultural woods with different stand age, separately for the mineral and litter layer samples, the Kruskal-Wallis test was applied. For this last analysis, recent woods were grouped into three age classes: the first class included stands up to 20 years old; the second included stands between 21 and 40 years, and the third between 41 and 60 years. Linear regression analysis was carried out between phosphomonoesterase activity and the $\mathrm{P}$ forms concentration and organic matter content on the enzyme activity. Variables were transformed (logarithmic or square root transformation) to show a linear relationship. Regression analysis was performed separately for litter and mineral layer in the ancient and recent woodlands. In addition, the KruskalWallis test was implemented to assess if there were differences in the $\mathrm{PH}_{\mathrm{ACID}}$ and $\mathrm{P}$ forms concentration according to soil type and humus type, treated as grouping variables. All statistical analyses were done using Statistica 8.1 package.

\section{Results}

Both layers of soils from ancient and post-agricultural alder woodlands differed significantly with respect to most of the properties investigated (Tab. 1). Acid phosphomonoesterase activity, organic matter, total, inorganic and organic $\mathrm{P}$ concentrations were significantly higher in soils from ancient alder woods than in soils from the recent ones (in the case of both soil depths). The level of available forms of $\mathrm{P}$ was also in accordance with that pattern; however, the significance of those differences was not confirmed statistically.

Significant differences in the available $\mathrm{P}$ concentration were observed between the litter and mineral layers in the same forest type. Similarly, phosphomonoesterase activity and organic matter content were significantly higher in the litter layer than to mineral one (Tab. 1). Such relations were present both in the case of ancient and post-agricultural forests. On the other hand the pattern of other $\mathrm{P}$ forms did not distinctively differ between soil depths within the same forest types. Besides, no significant differences between forest types and litter and mineral layers were recorded in the case of percentage share of organic $\mathrm{P}$ in total $\mathrm{P}$ and available $\mathrm{P}$ in inorganic $\mathrm{P}$ concentration (Tab. 1).

Although many soil properties measured changed with the forest-age classes of post-agricultural woods, most of these differences were insignificant according to the Kruskal-Wallis test results, probably due to the very narrow spectrum of age classes of recent alder stand. Significant differences were only recorded between the first (1-20 yrs) and the third (41-60 yrs) age classes in the case of the amount of organic matter and phosphomonoesterase activity, which increased with the age of alder stands, although only in the mineral layer of their soils (Tab. 2).

The relation between acid phosphomonoesterase activity and organic matter content was confirmed in the results of the regression analysis as it explained 69\%; $p$ level 0.000 (in the case of the mineral layer in ancient woods) to $71 \%$; $p$ level 0.000 ; in the litter layer of the ancient woods) of the variance. In the litter and mineral layers of recent woods it was calculated for $71 \%$; $p$ level 0.000 and $73 \%$; $p$ level 0.018 , respectively. Thus, the results of the linear regression analysis revealed that the organic matter content had a positive effect on the acid phosphomonoesterase activity. Since the activity of acid phosphomonoesterase did not show any particular behavior

Tab. 1 Mean and standard deviation $( \pm \mathrm{SD})$ values of $\mathrm{pH}$, phosphomonoesterase activity, organic matter content and $\mathrm{P}$ forms in the litter and mineral layers in ancient and recent alder forests.

\begin{tabular}{|c|c|c|c|c|}
\hline \multirow[b]{2}{*}{ Variable } & \multicolumn{2}{|c|}{ Litter layer } & \multicolumn{2}{|c|}{ Mineral layer } \\
\hline & Ancient $(N=27)$ & Recent $(N=27)$ & Ancient $(N=27)$ & Recent $(N=27)$ \\
\hline $\mathrm{pH}_{\mathrm{KCl}}$ & $4.81( \pm 0.70)$ & $4.85( \pm 0.73)$ n.s. & $4.94( \pm 0.75)$ n.s. & $4.90( \pm 0.84)$ \\
\hline $\mathrm{PH}_{\mathrm{ACID}}$ & $34.95( \pm 15.95)^{* *}{ }_{(\mathrm{xxxx})}$ & $24.36( \pm 10.87)_{(\mathrm{xxxx})}$ & $13.52( \pm 5.66)^{* * * *}$ & $7.71( \pm 2.87)$ \\
\hline $\mathrm{P}_{\text {AVAIL }}$ & $56.47( \pm 32.69)$ n.s. ${ }_{(\mathrm{xxx})}$ & $45.92( \pm 29.81)_{(\mathrm{xxx})}$ & $29.42( \pm 32.38)$ n.s. & $20.82( \pm 22.71)$ \\
\hline Organic matter & $27.57( \pm 13.01)^{*}{ }_{(\mathrm{xxx})}$ & $20.03( \pm 8.69)_{(\mathrm{xxx})}$ & $18.01( \pm 11.64)^{\star *}$ & $11.52( \pm 5.05)$ \\
\hline $\mathrm{P}_{\text {INORG }}$ & $0.14( \pm 0.05)^{\star \star \star}$ & $0.10( \pm 0.03)$ & $0.11( \pm 0.04)^{\star *}$ & $0.08( \pm 0.03)$ \\
\hline $\mathrm{P}_{\mathrm{ORG}}$ & $0.19( \pm 0.06)^{*}$ & $0.14( \pm 0.04)$ & $0.16( \pm 0.06)^{\star \star}$ & $0.12( \pm 0.04)$ \\
\hline$\% \mathrm{P}_{\mathrm{ORG}}$ in $\mathrm{P}_{\text {TOT }}$ & $56.87( \pm 3.62)$ & $57.44( \pm 4.49)$ & $60.12( \pm 4.28)$ n.s. & $59.90( \pm 6.55)$ \\
\hline$\% \mathrm{P}_{\text {AVAIL }}$ in $\mathrm{P}_{\text {INORG }}$ & $43.94( \pm 26.48)$ & $45.63( \pm 30.18)$ & $28.61( \pm 31.39)$ n.s. & $28.60( \pm 32.06)$ \\
\hline
\end{tabular}

n.s. - not significant; $\mathrm{P}_{\text {AVAIL }}$ - plant available phosphorus $\left(\mathrm{mg} \times \mathrm{kg}^{-1}\right) ; \mathrm{P}_{\text {INORG }}-$ inorganic phosphorus $\left(\mathrm{g} \times \mathrm{kg}^{-1}\right) ; \mathrm{P}_{\text {ORG }}-$ organic phosphorus $(\mathrm{g}$ $\left.\times \mathrm{kg}^{-1}\right) ; \mathrm{P}_{\text {тот }}$ - total phosphorus $\left(\mathrm{g} \times \mathrm{kg}^{-1}\right) ; \mathrm{PH}_{\mathrm{ACID}}-$ acid phosphomonoesterase activity $\left(\mathrm{mM} \mathrm{pNP} \times \mathrm{kg}^{-1} \times \mathrm{h}^{-1}\right) ; \mathrm{pH}_{\mathrm{KCl}}-$ exchangeable acidity. The differences between the forest types are marked with asterisks as follows: ${ }^{\star}$ Significance level according to the Mann-Whitney U-test, 0.01 $<p<0.05$; ${ }^{* *}$ Significance level according to the Mann-Whitney U-test, $0.001<p<0.01$; ${ }^{* *}$ Significance level according to the Mann-Whitney U-test, $0.0001<p<0.001{ }^{* * * *}$ Significance level according to the Mann-Whitney U-test, $p<0.0001$. The differences between the litter and mineral layer within the same forest type are marked in brackets, as follows: ${ }_{(\mathrm{xxx})}$ Significance level according to the Mann-Whitney U-test, $0.0001<p<0.001 ;{ }_{(\mathrm{xxxx})}$ Significance level according to the Mann-Whitney U-test, $p<0.0001$. 
Tab. 2 Mean and standard deviation $( \pm \mathrm{SD})$ values of $\mathrm{pH}$, phosphomonoesterase activity and $\mathrm{P}$ forms in the litter and mineral layers in the forest age classes of recent alder woods.

\begin{tabular}{|c|c|c|c|c|c|c|c|c|}
\hline \multirow[b]{3}{*}{ Variable } & \multicolumn{4}{|c|}{ Litter layer } & \multicolumn{4}{|c|}{ Mineral layer } \\
\hline & \multicolumn{3}{|c|}{ Recent woodland age } & \multirow[b]{2}{*}{$p$ level } & \multicolumn{3}{|c|}{ Recent woodland age } & \multirow[b]{2}{*}{$p$ level } \\
\hline & $1-20 \mathrm{yr}(N=11)$ & $21-40$ yr $(N=11)$ & $41-60 \mathrm{yr}(N=5)$ & & $1-20 \mathrm{yr}(N=11)$ & $21-40$ yr $(N=11)$ & $41-60$ yr $(N=5)$ & \\
\hline $\mathrm{pH}_{\mathrm{KCl}}$ & $4.93( \pm 0.73)$ & $4.97( \pm 0.75)$ & $4.43( \pm 0.65)$ & n.s. & $4.95( \pm 0.95)$ & $5.05( \pm 0.65)$ & $4.44( \pm 0.65)$ & n.s. \\
\hline $\mathrm{PH}_{\mathrm{ACID}}$ & $24.0( \pm 12.90)$ & $21.30( \pm 8.92)$ & $31.88( \pm 7.54)$ & n.s. & $6.36( \pm 2.04)$ & $7.65( \pm 2.15)$ & $10.83( \pm 3.77)$ & 0.0427 \\
\hline $\mathrm{P}_{\text {AVAIL }}$ & $43.26( \pm 22.54)$ & $39.31( \pm 30.70)$ & $66.33( \pm 38.59)$ & n.s. & $14.10( \pm 6.14)$ & $22.57( \pm 26.93)$ & $31.74( \pm 34.12)$ & n.s. \\
\hline Organic matter & $18.33( \pm 9.09)$ & $18.58( \pm 8.60)$ & $25.86( \pm 6.82)$ & n.s. & $10.03( \pm 5.22)$ & $11.30( \pm 4.23)$ & $15.30( \pm 5.34)$ & 0.0523 \\
\hline $\mathrm{P}_{\text {тот }}$ & $0.27( \pm 0.08)$ & $0.23( \pm 0.08)$ & $0.24( \pm 0.07)$ & n.s. & $0.22( \pm 0.07)$ & $0.18( \pm 0.04)$ & $0.19( \pm 0.08)$ & n.s. \\
\hline $\mathrm{P}_{\text {INORG }}$ & $0.12( \pm 0.03)$ & $0.10( \pm 0.03)$ & $0.09( \pm 0.02)$ & n.s. & $0.09( \pm 0.03)$ & $0.07( \pm 0.02)$ & $0.06( \pm 0.02)$ & n.s. \\
\hline $\mathrm{P}_{\mathrm{ORG}}$ & $0.15( \pm 0.05)$ & $0.13( \pm 0.04)$ & $0.14( \pm 0.06)$ & n.s. & $0.13( \pm 0.04)$ & $0.10( \pm 0.03)$ & $0.12( \pm 0.06)$ & n.s. \\
\hline$\% \mathrm{P}_{\mathrm{ORG}}$ in $\mathrm{P}_{\mathrm{TOT}}$ & $56.71( \pm 5.45)$ & $57.33( \pm 2.62)$ & $59.29( \pm 5.83)$ & n.s. & $59.25( \pm 4.88)$ & $58.44( \pm 8.15)$ & $64.55( \pm 4.38)$ & n.s. \\
\hline$\% \mathrm{P}_{\text {AVAIL }}$ in $\mathrm{P}_{\text {INORG }}$ & $38.33( \pm 18.41)$ & $41.33( \pm 27.00)$ & $71.18( \pm 47.29)$ & n.s. & $17.84( \pm 11.96)$ & $30.10( \pm 56.53)$ & $48.96( \pm 56.53)$ & n.s. \\
\hline
\end{tabular}

Refer to Tab. 1 for explanation of abbreviations.

according to soil and humus types, we were not showing the relative data. Additionally, because the results of the linear regression analyses between phosphomonoesterase activity and $\mathrm{P}$ forms did not show any statistical significance, we were not presenting them.

Among properties studied organic matter and $\mathrm{P}$ available content as well as $\mathrm{PH}_{\mathrm{ACID}}$ activity tended to be the most variable with a $C V$ value of $48.7 \%-111.6 \%$ (high variability). Other properties, like $\mathrm{P}_{\text {TOT, }}, \mathrm{P}_{\text {INORG }}$ and $\mathrm{P}_{\text {ORG }}$ concentration, showed a moderate to high variability $(C V=32.7-41.3 \%)$. Only exchangeable acidity $\left(\mathrm{pH}_{\mathrm{KCl}}\right)$ values were distributed more homogeneously across the studied area, which was shown by $C V$ values below $16.1 \%$ (Tab. 3). All properties studied were more variable in the mineral layer than in the litter one.

Tab. 3 Coefficient of variation (\%) of properties studied for soil depths and forest types.

\begin{tabular}{lcccc} 
Parameters & Ancient & Recent & Litter layer & Mineral layer \\
\hline $\mathrm{pH}_{\text {KCl }}$ & 14.8 & 16.0 & 14.7 & 16.1 \\
Organic matter (\%) & 56.5 & 52.2 & 48.7 & 64.1 \\
$\mathrm{PH}_{\text {ACID }}$ & 66.5 & 71.9 & 49.0 & 50.1 \\
$\mathrm{P}_{\text {AVAIL }}$ & 81.8 & 87.4 & 61.4 & 111.6 \\
$\mathrm{P}_{\text {TOT }}$ & 37.0 & 32.7 & 34.3 & 38.7 \\
$\mathrm{P}_{\text {INORG }}$ & 36.9 & 34.8 & 34.9 & 41.3 \\
$\mathrm{P}_{\text {ORG }}$ & 37.5 & 33.3 & 35.7 & 39.5 \\
\hline
\end{tabular}

Mean values for $0-5 \mathrm{~cm}$ and $5-15 \mathrm{~cm}$ as well as for the age ranges $(N=54)$. Refer to Tab. 1 for explanation of abbreviations.

\section{Discussion}

A significantly higher acid phosphatase activity in ancient than in recent stands as well as in post-agricultural woods from the third age class (41-60 yrs) as compared to younger recent forests (Tab. 1, Tab. 2) to some extent seem to confirm Binkley's theory [14] on the activating influence of alder stands on this enzyme, which is produced and secreted in such soils.
According to Binkley [25] N-fixing trees such as alders contribute to an increase in the rate of the uptake and return of a nutrient to the soil, simultaneously increasing soil fertility. Some authors state that nitrogen-fixing trees may alter the concentration of available P in soils $[10,25]$. However, such clear effect of black alder was not confirmed in our study. Although $\mathrm{P}_{\text {AVAIL }}$ content as well as the percentage share of available $\mathrm{P}$ in inorganic $\mathrm{P}$ concentration increased clearly with the age of the recent woods, the significance was not confirmed statistically. This might probably be due to extremely high variation of the results indicated by standard deviation (SD; Tab. 1) and $C V$ (\%) values (Tab. 3). Simultaneously, the contribution of $P_{O R G}$ in $\mathrm{P}_{\text {тот }}$ remained similar in ancient and recent forest as well as among post-agricultural woods of different age. In some cases a decline in the concentration of available $\mathrm{P}$ under red alders was observed [10], whereas in other cases an opposite observation was made $[12,13]$. The presence of $\mathrm{N}$-fixing red alders appears to contribute to an increase in the available $\mathrm{P}$ concentration in mixed stands [26], while red alder in pure stands appeared to decrease it [27].

According to the classes based on the coefficient of variation (\%) values proposed by Wilding [24] among the soil properties assessed the coefficient was very small only in the case of $\mathrm{pH}_{\mathrm{KCl}}$, while acid phosphatase activity, available $\mathrm{P}$ and organic matter content showed a high magnitude of variability (Tab. 3). Usually, soil biological parameters, including enzymatic activity are considered to have high heterogeneity [28]. As already mentioned enzymatic activity is significantly controlled by such soil properties as organic matter content, soil moisture or $\mathrm{pH}$ values [29]. In our study, however, the variability of organic matter content could only be a source of variability for $\mathrm{PH}_{\mathrm{ACID}}$ activity since soil reaction exhibited low $C V$ values.

Previous results showed that soils under older stands contained the larger amounts of organic $\mathrm{C}$ and total $\mathrm{N}$ than those under recent ones [18]. In the alder woods which we studied organic matter content was always higher in ancient woodland soils than in recent ones and increased in mineral layer of soil with age of recent woods. Such a relation is probably due to the larger biomass of accumulated litter containing more alder leaves which, once decomposed, contribute to the increase in soil organic matter content. Consistently, 
higher organic matter content contributed to an increase in phosphatase activity what was confirmed by the results of the linear regression analysis. Our observations are in accordance with findings of Amador et al. [30] who reported that in riparian forest soils the distribution of phosphatase in moderately wet and poorly drained sites is determined mainly by organic matter and moisture. Close relationship between phosphomonoesterase activity and soil organic matter content is common and reported for many arable and forest soils [31,32].

The activity of enzymes and the content of available forms of nutrients in soil profile samples usually decrease with depth. It is paralleled by a decrease in organic matter and the diminution of biological activity down the profile as well as with worsening air-water conditions [33]. Such observations were confirmed in the course of our studies since soil acid phosphatase activity, organic matter and available $\mathrm{P}$ content were largely concentrated in a litter layer and decreased significantly at a mineral depth (Tab. 1, Tab. 2). As stated by Wittmann et al. [34] the maximum activity at the top of the forest soil may be linked with substrate availability, because most of the organic substrate entering the soil is in the forest litter. Since the values of biological parameters decrease significantly along with soil profile depth, the top layers of the horizon seem to be most appropriate for investigating changes in forest soils.

In our study no significant relationship between phosphatase activity and any of $\mathrm{P}$ forms was observed. This is in contrast with some previous results, obtained by other authors $[30,35,36]$. However, they refer to different soils and plant species. As already mentioned the relationship between the available $\mathrm{P}$ concentration and phosphatase activity may be very complex $[4,5]$. When no relationship is seen between $\mathrm{PH}_{\mathrm{ACID}}$ activity and $\mathrm{P}_{\text {AVAIL }}, \mathrm{P}$ may not limit the system but some other factors may influence the enzyme production and activity, for example $\mathrm{N}$ availability [1] or interaction between enzyme and humus or clay [37].

\section{Conclusions}

The influence of black alder on the activity of acid phosphatase and $\mathrm{P}$ forms was ambiguous. The absence of a statistically significant response in the $\mathrm{P}$ forms content and phosphatase activity (in litter layer) related to the growing age of black alder recent stands and no clear relationship between phosphatase activity and $\mathrm{P}$ forms, are possibly due to very narrow range of age classes of alder stands available for studies. Thus, further investigations are required in older post-agricultural stands. Moreover, the mechanisms responsible for potentially activating impact of black alder on the level of phosphatases are worth further studies. Among the potential issues to be investigated are: $(\boldsymbol{i})$ estimation to what degree black alder trees contribute to the production of phosphatase enzymes through their exudation from roots and how much enzymatic activity originates from leaf litter from alders and (ii) the role of actinorrhizal fungi, which are associated with black alder in the phosphatase activity. This knowledge about such an important $\mathrm{N}$-fixer, pioneer species such as black alder would be of great value since this tree is often used for afforestation in many parts of Europe, not only in semi-natural ecosystems like meadows, but also in derelict, contaminated land with extremely poor soils.

\section{References}

1. Olander LP, Vitousek PM. Regulation of soil phosphatase and chitinase activity by $\mathrm{N}$ and $\mathrm{P}$ availability. Biogeochemistry. 2000;49(2):175-191. http://dx.doi. org/10.1023/A:1006316117817

2. Yadav RS, Tarafdar JC. Influence of organic and inorganic phosphorus supply on the maximum secretion of acid phosphatase by plants. Biol Fert Soils. 2001;34(3):140-143. http://dx.doi.org/10.1007/s003740100376

3. Makoi JHJR, Ndakidemi PA. Selected soil enzymes: examples of their potential roles in the ecosystem. Afr J Biotechnol. 2008;7(3):181-191.

4. Miller SS, Liu J, Allan DL, Menzhuber CJ, Fedorova M, Vance CP. Molecular control of acid phosphatase secretion into the rhizosphere of proteoid roots from phosphorusstressed white lupin. Plant Physiol. 2001;127(2):594-606. http://dx.doi.org/10.1104/pp.010097

5. Sinsabaugh RL, Antibus RK, Linkins AE, McClaugherty CA, Rayburn L, Repert D, et al. Wood decomposition: nitrogen and phosphorus dynamics in relation to extracellular enzyme activity. Ecology. 1993;74(5):1586. http:// dx.doi.org/10.2307/1940086

6. Juma NG, Tabatabai MA. Distribution of phosphomonoesterases in soils. Soil Sci. 1978;126:101-108.

7. Šarapatka B. Phosphatase activities (ACP, ALP) in agroecosystem soils [PhD thesis]. Uppsala: Swedish University of Agricultural Sciences; 2003.

8. Laganis J. Emergy analysis of black alder [Alnus glutinosa (L.) Gaertn.] floodplain forest growth [PhD thesis]. Nova Gorica: University of Nova Gorica; 2007.

9. Roy S, Khasa DP, Greer CW. Combining alders, frankiae, and mycorrhizae for the revegetation and remediation of contaminated ecosystems. Can J Bot. 2007;85(3):237-251. http://dx.doi.org/10.1139/B07-017

10. Compton JE, Cole DW. Phosphorus cycling and soil $\mathrm{P}$ fractions in Douglas-fir and red alder stands. Forest Ecol Manag. 1998;110(1-3):101-112. http://dx.doi.org/10.1016/ S0378-1127(98)00278-3

11. Binkley D, Giardina C. Why do tree species affect soils? The warp and woof of tree-soil interactions. Biogeochemistry. 1998;42(1):89-106. http://dx.doi. org/10.1023/A:1005948126251

12. Bormann BT, Cromack K, Russell III WO. Influence of red alder on soils and long-term productivity. In: Hibbs DE, de Bell DS, Tarrant RF, editors. The biology and management of red alder. Corvallis OR: Oregon State University Press; 1994. p. 47-56.

13. Giardina CP, Huffman S, Binkley D, Caldwell BA. Alders increase soil phosphorus availability in a Douglas-fir plantation. Can J For Res. 1995;25(10):1652-1657. http://dx.doi. org/10.1139/x95-179

14. Binkley D. Forest nutrition management. New York: Wiley; 1986.

15. de Keersmaeker L, Martens L, Verheyen K, Hermy M, de Schrijver A, Lust N. Impact of soil fertility and insolation on diversity of herbaceous woodland species colonizing afforestations in Muizen forest (Belgium). Forest Ecol Manag. 2004;188(1-3):291-304. http://dx.doi.org/10.1016/j. foreco.2003.07.025

16. Koerner W, Dupouey JL, Dambrine E, Benoit M. Influence of past land use on the vegetation and soils of present day forest in the Vosges Mountains, France. J Ecol. 
1997;85(3):351. http://dx.doi.org/10.2307/2960507

17. Peterken GF. A method for assessing woodland flora for conservation using indicator species. Biol Conserv. 1974;6(4):239-245. http://dx.doi. org/10.1016/0006-3207(74)90001-9

18. Orczewska A. The impact of former agriculture on habitat conditions and distribution patterns of ancient woodland plant species in recent black alder [Alnus glutinosa (L.) Gaertn.] woods in south-western Poland. Forest Ecol Manag. 2009;258(5):794. http://dx.doi.org/10.1016/j. foreco.2009.05.021

19. Orczewska A. Age and origin of forests in south-western Poland and their importance for ecological studies in mandominated landscapes. Landscape Res. 2009;34(5):599-617. http://dx.doi.org/10.1080/01426390903184579

20. World reference base for soil resources. Rome: FAO, ISSS, ISRIC; 1998.

21. Prusinkiewicz Z. Wielojęzyczny słownik terminów z zakresu próchnic leśnych. Warsaw: Polish Scientific Publishers PWN; 1988.

22. Tabatabai MA, Bremner JM. Use of $p$-nitrophenyl phosphate for assay of soil phosphatase activity. Soil Biol Biochem. 1969;1(4):301-307. http://dx.doi. org/10.1016/0038-0717(69)90012-1

23. Mehta NC, Legg JO, Goring CA, Black CA. Determination of organic phosphorus in soils. Soil Sci Soc Amer Proc. 1954;44:443-449.

24. Wilding LP. Spatial variability: its documentation, accommodation, and implication to soil surveys. In: Nielsen LR, Bouma J, editors. Wageningen: Pudoc; 1985. p. 166-194.

25. Binkley D. Mixtures of nitrogen-fixing and non-nitrogenfixing tree species. In: Cannell MGR, Malcolm DC, Robertson PA, editors. The ecology of mixed-species stands of trees. Oxford: Blackwell Scientific; 1992. p. 99-123.

26. Zou X, Binkley D, Caldwell BA. Effects of dinitrogen-fixing trees on phosphorus biogeochemical cycling in contrasting forests. Soil Sci Soc Am J. 1995;59(5):1452. http://dx.doi. org/10.2136/sssaj1995.03615995005900050035x

27. Compton JE, Homann PS, Cole DW. Leaf element concentrations and soil properties in successive rotations of red alder (Alnus rubra). Can J For Res. 1997;27:662-666.

28. Peigné J, Vian JF, Cannavacciuolo M, Bottollier B, Chaussod
R. Soil sampling based on field spatial variability of soil microbial indicators. Eur J Soil Biol. 2009;45(5-6):488-495. http://dx.doi.org/10.1016/j.ejsobi.2009.09.002

29. Elsebai T, Lagacherie B, Soulas G, Martinlaurent F. Spatial variability of isoproturon mineralizing activity within an agricultural field: Geostatistical analysis of simple physicochemical and microbiological soil parameters. Environ Pollut. 2007;145(3):680-690. http://dx.doi.org/10.1016/j. envpol.2006.05.034

30. Amador JA, Glucksman AM, Lyons JB, Görres JH. Spatial distribution of soil phosphatase activity within a riparian forest. Soil Sci. 1997;162(11):808-825. http://dx.doi. org/10.1097/00010694-199711000-00005

31. Sinsabaugh RL, Lauber CL, Weintraub MN, Ahmed B, Allison SD, Crenshaw C, et al. Stoichiometry of soil enzyme activity at global scale. Ecol Lett. 2008;11:1252-1264. http:// dx.doi.org/10.1111/j.1461-0248.2008.01245.x

32. Hýsek J, Šarapatka B. Relationship between phosphatase active bacteria and phosphatase activities in forest soils. Biol Fertil Soils. 1997;26(2):112-115. http://dx.doi.org/10.1007/ s003740050352

33. Ekenler M, Tabatabai MA. Responses of phosphatases and arylsulfatase in soils to liming and tillage systems. J Plant Nutr Soil Sci. 2003;166(3):281-290. http://dx.doi. org/10.1002/jpln.200390045

34. Wittmann C, Kähkönen MA, Ilvesniemi H, Kurola J, Salkinoja-Salonen MS. Areal activities and stratification of hydrolytic enzymes involved in the biochemical cycles of carbon, nitrogen, sulphur and phosphorus in podsolized boreal forest soils. Soil Biol Biochem. 2004;36(3):425-433. http://dx.doi.org/10.1016/j.soilbio.2003.10.019

35. Chen H. Phosphatase activity and P fractions in soils of an 18-year-old Chinese fir (Cunninghamia lanceolata) plantation. Forest Ecol Manag. 2003;178(3):301-310. http:// dx.doi.org/10.1016/S0378-1127(02)00478-4

36. Kang H, Freeman C. Phosphatase and arylsulphatase activities in wetland soils: annual variation and controlling factors. Soil Biol Biochem. 1999;31(3):449-454. http:// dx.doi.org/10.1016/S0038-0717(98)00150-3

37. Kang H, Kang S, Lee D. Variations of soil enzyme activities in a temperate forest soil. Ecol Res. 2009;24(5):1137-1143. http://dx.doi.org/10.1007/s11284-009-0594-5 